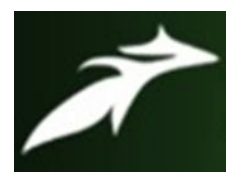

Debashis Kuila et al, International Journal of Advances in Agricultural Science and Technology,

Vol.7 Issue.12, December-2020, pg. 71-80

ISSN: 2348-1358

Impact Factor: 6.057

NAAS Rating: 3.77

\title{
Effect of Arbuscular Mycorrhiza and Fly Ash Amendment in Red Lateritic Soil to Compare the Chilli Growth
}

\author{
Debashis Kuila $^{1 *}$; Bijoy Mal$^{2}$; Sudip Mondal ${ }^{2}$; Somdatta Ghosh ${ }^{3}$; Gunjan Biswas ${ }^{2}$ \\ ${ }^{1}$ Mycorrhiza \& Microbiology Research Section, UG \& PG Department of Botany, Midnapore College \\ (Autonomous); Department of Botany and Forestry, Vidyasagar University, Midnapore, W.B., India \\ Email: dk89ian@gmail.com \\ ${ }^{2}$ Department of Botany and Forestry, Vidyasagar University, Midnapore 721102, W.B., India \\ Email: gbiswas1211@gmail.com \\ ${ }^{3}$ PG \& UG Department of Botany, Midnapore College (Autonomous), Midnapore, W.B., India \\ Email: somdattaghosh@yahoo.co.in \\ DOI: 10.47856/ijaast.2020.v07i12.011
}

\begin{abstract}
Application of fly ash with soil may act as a source of readily available micro and macro nutrients to the plants and improve physico-chemical and biological properties of the soil. In contrast lateritic soil is low fertile, deficient in available phosphorus and other nutrients to the plants. In the experiment Capsicum annuum (chilli) were grown as test crops planted in lateritic soil and fly ash separately, and in the combined mixture of them, with inoculation of the arbuscular mycorrhiza, Acaulospora delicata. Parameters were compared for AM spore count, root colonization, growth and productivity of chilli in term of height, leaf number, leaf area, root collar dimeter, number of flowers and fruits, fresh weight and dry weight. Among all soil samples the growth of chilli showed maximum in combined mixture of lateritic soil and fly ash inoculated with the AM. Also the combined treatment of AM inoculated lateritic soil and fly ash showed better mycorrhization than others. Hence application of AM inoculated low fertile soil with fly ash may present better productivity.
\end{abstract}

Keywords: AM, Acaulospora, Mycorrhization, Lateritic Soil, Yield.

\section{INTRODUCTION}

The lateritic soil is acidic and dry in nature with less fertility. The soil is deficient in basic essential elements like, phosphorus, nitrogen, calcium, magnesium etc. Heavy leaching due to acidity resulting soil infertility, and nutrients remain unavailable to the plant (Koley, 2000).

Fly ash is the residue being generated as byproduct from coal based thermal power stations, that its huge depositions are problematize as air and water pollution. It is highly alkaline (Adriano et al., 1998). The amorphous mixture contains several essential plant nutrients $\mathrm{C}, \mathrm{Ca}, \mathrm{Cu}, \mathrm{Fe}, \mathrm{K}, \mathrm{Mg}, \mathrm{Na}, \mathrm{Zn}$ etc. (Pandey et al., 1994; Singh et al., 1997; Tiwari et al., 2008). The amorphous, heterogeneous mixture improves soil properties (Weinstein et al., 1989) and provides plant growth (Aitken and Bell, 1985; Sharma et al., 1990). Application of fly ash may provide positive influence to the plants and increase the crop productivity.

Arbuscular mycorrhiza (AM) are the widely occurring, obligatory aerobic, non-pathogenic soil fungi develops symbiotic relationship with the plant roots (Harley and Smith, 1983). They plays important roles to enhance the water and nutrient uptake particularly phosphorus and nitrogen with other essential micronutrients 


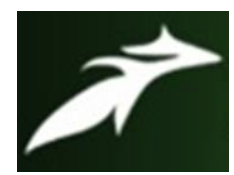

Debashis Kuila et al, International Journal of Advances in Agricultural Science and Technology, Vol.7 Issue.12, December-2020, pg. 71-80

ISSN: 2348-1358

Impact Factor: 6.057

NAAS Rating: 3.77

by altering of some physiological processes in plants, improve plant growth and yield (Douds et al., 2005). Application of AM maybe a substitute for chemical fertilizer particularly in this dry acidic soil. They can improve the physical properties of fly ash by providing the aggregation of fly ash and increase the growth and nutrient uptake of plants (Enkhtuya et al., 2005).

Arbuscular mycorrhizal fungi (AMF) have been used as bioremediation agents (Leyval and Haselwander, 1997). Inoculation of AM fungi may promote the alleviation of heavy metal phytotoxicity, and thus, reduction of toxic metals take place (Juwarkar and Jambhulkar, 2008). AM fungi have a key role to accumulate the heavy metals from fly ash and able to suppress the uptake of toxic Al, Mn etc. (Chen et al., 2007; Ning, 2000). AMF can be used as effective bio-inoculant for agricultural plants (Lakshman, 2009), particularly in the infertile lateritic soil, combined with fly ash amendment, as the fly ash and AM both are reclamation agent, if these three work together, may be more effective.

\section{MATERIALS AND METHODS}

The experiment was conducted with chilli (Capsicum annuum L.) planted in sterilized lateritic soil collected from barren land was done in $22.30^{\circ} \mathrm{N}$ Latitude and $87.20^{\circ}$ E Longitude in Midnapore subdivision of West Bengal in pre-winter season. The primary soil characteristics were tested according to Jackson (1973), having $\mathrm{pH} 5.5$, electrical conductivity (EC) of $0.17 \mathrm{~m} \mathrm{mohs} / \mathrm{cm}^{2}$, moisture content of $2.8 \%$, organic carbon (OC) of $0.62 \mathrm{~g} \mathrm{~kg}^{-1}$, total nitrogen (N) of $0.042 \%$ and phosphate $(\mathrm{P})$ of $0.031 \%$.

Separation and isolation of indigenous AM propagules from the native ecosystem was done by following the wet sieving and decanting technique (Gerderman and Nicolson, 1963). Spores of single species were separated morphologically using a LABOMED CSM2 microscope, and surface sterilized by $200 \mu \mathrm{g} \mathrm{ml}{ }^{-1}$ streptomycin and 2\% Chloramine-T solution (w/v) (Mosse, 1973).

The pure culture of each inoculum was cultured in sterilized sand: soil mixture. The soil: sand (1:1, v/v) mixture was sterilized by oven drying at $85^{\circ} \mathrm{C}$ (Sylvia, 1994). Pure cultures were done in funnels and mass cultures in surface-sterilized earthen pots, grown in an automated growth chamber with sorghum plants. The mass cultures were maintained up to 90 days in the growth chamber.

The successful mass culture of the indigenous AM inocula was identified morphologically by following Schenk and Prez (1990) and the INVAM web photo guide (2018) and confirmed as Acaulospora delicata.

Fly ash was collected from ash deposited area with vegetation in Kolaghat Thermal power station, Kolaghat, Purba Medinipur, West Bengal. The experiment was designed in a randomized block with eight treatments and three replicates consisted with two control, Lateritic Soil (LS) and, Fly Ash (FA), the combined mixture in 1:1 ratio of Lateritic Soil + Fly Ash (LS + FA), Lateritic Soil + AM, Acaulospora delicata (LS + AM), Fly Ash + AM (FA + AM), and Lateritic Soil + Fly Ash + AM (LS + FA + AM). 


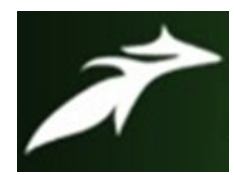

Debashis Kuila et al, International Journal of Advances in Agricultural Science and Technology, Vol.7 Issue.12, December-2020, pg. 71-80

ISSN: 2348-1358

Impact Factor: 6.057

NAAS Rating: $\mathbf{3 . 7 7}$

Surface sterilized seeds of chilli were germinated in aseptic conditions and seeded with a $10 \mathrm{~cm}$ gap from each other. Moderate watering was done every day. After germination, the healthy chilli seedlings were transferred with different treatments and grown for 90 days in polythene bags $(18$ X $24 \mathrm{~cm})$.

Parameters were measured in terms of shoot height, leaf number per plant, leaf area, the total number of flower and pod appeared per plant, plant fresh and dry weight.

Rhizospheric soil samples were tested for the AM spore population by wet sieving and decanting technique (Gerderman and Nicolson, 1963). Plant root samples were treated with $10 \% \mathrm{KOH}$ and stained with tryphan blue (Phillips and Hayman, 1970) to study the colonization percentage by the formula,

$$
\text { Root colonization } \%=\left(\frac{\text { Number of root pieces colonized }}{\text { Total number of root pieces observed }}\right) \times 100
$$

Statistical analysis of data was done by using IBM SPSS 20.

\section{RESULTS AND DISCUSSION}

The effect of AM inoculation increased measured growth parameters from the early stage. After 30 days of the plantation (dap), $\mathrm{LS}+\mathrm{FA}+\mathrm{AM}$ showed maximum height followed by FA + AM and LS + AM (Figure 1). Root colonization was also found maximum in LS + AM followed by LS + FA + AM and FA + AM (Figure 2). The control LS performed the poorest among all the treatments, and others were more effective than control, and the similar observation was reflected in the rest of the period of the experiment.

In 60 dap, the height was maximum in LS + FA + AM followed by FA + AM and LS + AM (Figure 1). The Mycelium infection \% was increased in LS + FA + AM treatment, followed by LS + AM, FA + AM and FA (Figure 2). Root colonisation in LS + AM and FA + AM was found same.

In 90 dap, LS + FA + AM was also found best in all treatments. The maximum plant height was observed in LS + FA + AM followed by FA + AM, LS + AM and LS + FA (Table 1). The shoot height of C.annuum grown in LS + FA was $19.55 \%$, and in LS + AM was $15.08 \%$ better than LS. While, shoot height in $\mathrm{LS}+\mathrm{FA}$ and FA + AM were found $8.62 \%$ and $28.42 \%$ more than the FA. In LS + FA + AM, shoot height was increased $77.65 \%$ than LS, and $61.42 \%$ than the FA. In the final observation, LS + FA + AM worked better. Other fly ash applied treatments i.e., FA + AM, LS + FA, and FA performed poorer than LS + FA + AM; where no AM inoculated treatments i.e., LS + FA and FA were slightly better than LS (at p<0.05). The rest of the other co-parameters were also found maximum in LS + FA + AM. The total fruit number was found maximum in LS $+\mathrm{FA}+\mathrm{AM}$ followed by FA + AM, LS + AM and FA. The total fresh yield per plant was also found maximum in LS + FA + AM with same pattern. The fresh yield in LS + FA was increased $49.55 \%$ more, and in LS + AM, increased $124.77 \%$ more than in LS. The same was found with $94.85 \%$ increment in FA + AM than the FA. But, the final yield was declined in LS + FA, 3.42\% less than FA. While, the fresh yield was increased 3.52 times and 2.27 times more in LS + FA + AM than LS (252.21\% increment) and FA (127.42\% increment) respectively. 


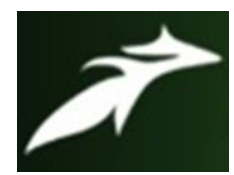

Debashis Kuila et al, International Journal of Advances in Agricultural Science and Technology, Vol.7 Issue.12, December-2020, pg. 71-80

ISSN: 2348-1358

Impact Factor: 6.057

NAAS Rating: 3.77

A similar result was observed in the total dry yield per plant. Mycorrhizal colonization and spore number were found positively co-related with height, leaf number, leaf area and fruit number $(\mathrm{p}<0.05)$. AM root colonization and total spore population were found maximum in LS + FA + AM throughout the experiment. Fresh weight and dry weight of total yield were also found directly correlated with plant height and mycorrhization $(\mathrm{p}<0.05)$.

From the experiment it was found that the root colonisation percentage as well as mycorrhizal infectivity class was maximum in AM inoculated and lateritic soil with fly ash amendment. Also the spore number and the fresh weight was maximum into that treatment. AM inoculated and lateritic soil with fly ash amendment also showed better to induce productivity more than the others treatments. Thus AM root colonisation shows the positive influence into that treatment. This preliminary pot study indicates that can be improved by colonization of the plant roots by mycorrhizal fungi.

In all the AM applied treatments, Mycelium infection \% and spore formation occurred. This indicates that mycorrhization took place in a normal way within those treatments. In lateritic soil the AM propagules are low and the mycorrhizal application increased the growth and yield (Ghosh and Verma, 2006). The dry lateritic soil is deficient in phosphorus as well as nitrogen and other essential less mobile nutrients because of slow nutrient cycling (Koley, 2000). AM are more active in nutrient-poor dry soils, plants depended more on mycorrhizae for nutrients and moisture in this condition (Brundrett, 2009). Acaulospora delicata are the dominant species present in lateritic environment, promoting active participation in mycorrhization with test plant (Samanta and Verma, 2006; Ghosh and Verma, 2011). Active mycorrhization in the plants alters some physiological processes and increases water and nutrient uptake which enhances crop growth and yield (Douds et al., 2005). Fly ash addition into the lateritic soil, may be decreased the bulk density and increases the water holding capacity (Black 1965). The AMF are able to bind the fine particles in fly ash, and also can arrest the movement of heavy metals, and uptake the phosphorus and other important micronutrients (Adholeya, 2000).

By aggregating the particles present in fly ash, AM fungi enhance the nutrient uptake and induce the growth of plants and (Wu et al., 2009). Fly ash contains many essential plant nutrients (Plank et al., 1975; Singh et al., 1997). In LS + FA + AM, fly ash increased the plant growth as well as mycorrhizal root colonisation, increased tolerance of mycorrhizal plants to toxic heavy metal ions in the fly ash mixed lateritic soil. AM fungi reduce the metal effect in host plant by binding of the metals to the fungal mycelium and immobilize them in rhizosphere or roots (Chen et al. 2001). According to Srivastava and Chhonkar (2000), fly ash can be used as an alternative to lime source in acidic soil to reduce nutrient immobilization due to acidity. Thus the macro and micro-nutrient enriched fly ash can be used as a nutrient resource for plants particularly in infertile acidic soil 


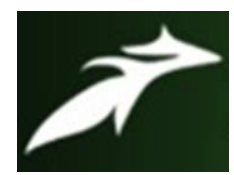

Debashis Kuila et al, International Journal of Advances in Agricultural Science and Technology, Vol.7 Issue.12, December-2020, pg. 71-80

ISSN: 2348-1358

Impact Factor: 6.057

NAAS Rating: 3.77

(Sheela and Sundaram, 2003). Hence the mycorrhizal inoculation with the reclamation of lateritic soil by fly ash may induce better productivity and reduced the application of chemical fertilizers as well as metal detoxification of environment.

\section{CONCLUSION}

Application of indigenous AM, Acaulospora delicata along with fly ash reclamation facilitated plants with better growth and enhanced the yield of green chilies grown in infertile dry and acid lateritic soil. This application may benefit in agriculture practice particularly in less nutrient soil, which can reduce the cost in comparison to chemical fertilizers.

\section{ACKNOWLEDGEMENT}

We are very grateful to the University Grant Commission (UGC), Government of India for the financial assistance to conduct the research work.

\section{REFERENCES}

[1] Adholeya A., 2000. Utilization of fly ash for commercial plant production and environmental protection using Microbes. In Proceedings of Second International Conference on Fly Ash Disposal and Utilization, New Delhi, vol. II, pp. 32-35.

[2] Adriano D.C., Woodford T.A., Ciravolo T.G., 1978. Growth and elemental composition of corn and bean seedlings as influenced by soil application of coal ash. J. Environ. Qual. 7: 416-421.

[3] Aitken R.L., Bell L.C., 1985. Plant uptake and phytotoxicity of Boron in Australian fly ashes. Plant and Soil. 84: 245-257.

[4] Black C.A., 1965. Methods of soil analysis. (Part I and II). American Society of Agronomy. Publishers Madison, Wisconsin, USA.

[5] Brundrett M. C., 2009. Mycorrhizal associations and other means of nutrition of vascular plants: understanding the global diversity of host plants by resolving conflicting information and developing reliable means of diagnosis. Plant Soil. 320: 1-41.

[6] Chen B. D., Zhu Y.G., Duan J., Xiao X. Y., \& Smith S. E. (2007). Effects of the arbuscular mycorrhizal fungus Glomus mosseae on growth and metal uptake by four plant species in copper mine tailings. Environmental Pollution. 147: 374-380.

[7] Chen B.D., Christie P., Li X.L., 2001. A modified glass bead compartment cultivation system for studies on nutrient uptake by arbuscular mycorrhiza. Chemosphere. 42: 185-192.

[8] Douds D.D., Nagahashi G., Pfeffer P.E., Kayser W.M., and Reider C., 2005. On-farm production and utilization of arbuscular mycorrhizal fungus inoculum. Can. J. Plant Sci. 85: $15-21$.

[9] Enkhtuya B., Poschl M., and Vosatka M., (2005). Native grass facilitates mycorrhizal colonization and $\mathrm{P}$ uptake of tree seedlings in two anthropogenic substrates. Water, Air, and Soil Pollution, 166, 217-236. 


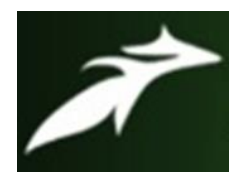

Debashis Kuila et al, International Journal of Advances in Agricultural Science and Technology, Vol.7 Issue.12, December-2020, pg. 71-80

ISSN: 2348-1358

Impact Factor: 6.057

NAAS Rating: 3.77

[10]Gerdemann J. W., and Nicolson T. H., 1963. Spores of mycorrhizal Endogone species extracted from soil by wet sieving and decanting. Transactions of the British Mycological Society, 46: 235-244.

[11] Ghosh S., and Verma N.K., 2006. Growth and mycorrhizal dependency of Acacia mangiumWilld. inoculated with three vesicular arbuscular mycorrhizal fungi in lateritic soil. New Forests, 31:75-81.

[12]Harley J. L. ,and Smith S. E., 1983. Mycorrhizal symbiosis ( $1^{\text {st }}$ ed.). Academic Press, London.

[13]INVAM, 2018. Classification, International Culture Collection of Vesicular Arbuscular Mycorrhizal Fungi. Available in: https:// invam.wvu.edu

[14] Jackson M. L., 1973. Soil chemical analyses, pp.111-120. Prentice Hall, New Delhi, India.

[15] Juwarkar A.A., and Jambhulkar H.P., 2008. Restoration of fly ash dump through biological interventions. Environ Monit Assess. 139: 355-365.

[16] Koley, A.K., 2000. Basic concepts of soil-Science, New Age International Publishers. New Delhi, India. $2^{\text {nd }}$ ed

[17]Lakshman H.C., 2009. Importance of AM fungal technology for sustainable agriculture. In the proceedings of NAS - Bangalore ICAR - National conference, pp: 19-23.

[18] Leyval C., Turnau K., and Haselwandler K., 1997. Effect of heavy metal pollution on mycorrhizal colonization and function: physiological, ecological and applied aspect. Mycorrhiza. 7: 139-153.

[19] Mosse B., 1973. Advances in the study of vesicular arbuscular mycorrhiza. Ann. Rev. Phytopath., 11: 171-196.

[20]Ning J., 2000. Mycorrhizal roles in broomsedge plants under phosphorus limitation and aluminum toxicity. PhD dissertation, West Virginia University, Morgantown WV, USA.

[21]Pandey V., Mishra J., Singh S. N., Sing, N., Yunus M., and Ahmad K. J., (1994). Growth response of Helianthus annuus L. grown on fly-ash amended soil. Journal of Environmetal Biology, 15, 117-125.

[22]Phillips J.M., and Hayman D.S., 1970. Improved procedure for clearing roots and staining parasitic and vesicular arbuscular mycorrhizal fungi for rapid assessment of infection. Trans Br. Mycol. Soc., 55: $158-161$.

[23]Plank C.O., Martens D.C., and. Hallock D.L., 1975. Effect of soil application of fly ash on chemical composition and yield of corn (Zea mays L.) and on chemical composition of displaced soil solutions. Plant Soil. 42:465-476.

[24] Samanta S., Verma N.K., 2006. Effect of VA mycorrhiza on the growth and protein content in fruits of Capsicum annuum grown in acid lateritic soil. J Mycopathol Res., 44 (2): 197-200.

[25] Sampath Kumar G., and Murugesh S., 2002. Studies on the VAM fungi improves growth of some medicinal plants. Ad. Plant. Sci., 15(1): 43-46.

[26] Schenck N.C., and Pérez Y., 1990. Manual for the identification of VA mycorrhizal fungi, (INVAM), $3^{\text {rd }}$ Ed., FL: Synergistic Publications. University of Florida, Gainesville.

[27] Sharma B.M., Aggarwal R.K., and Kumar P., 1990. Water retention and nutrient availability in a fly ash amended desert sandy soil: A study in vitro. Arid Soil Res. Rehab., 4: 53-58.

[28] Sheela M.A., and Sundaram M.D., 2003. Role of VA-mycorrhizal biofertilizer in establishing black gram (Vigna mungo L.) var -T9 in abandoned ash ponds of Neyveli Thermal Power Plant. Mycorrhiza News, 15 (2): 13-16. 


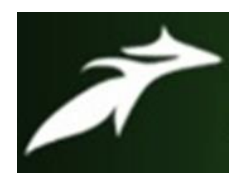

Debashis Kuila et al, International Journal of Advances in Agricultural Science and Technology,

Vol.7 Issue.12, December-2020, pg. 71-80

ISSN: 2348-1358

Impact Factor: 6.057

NAAS Rating: 3.77

[29] Singh A.K., Singh R.B., Sharma A.K., Gauraha R., and Sagar S., 1997. Response of fly-ash on growth of Albizia procera in coal mine spoil and skeletal soil. Environmental Ecology. 15: 585-591.

[30] Singh A.K., Singh R.B., Sharma A.K., Gauraha R., and Sagar S., 1997. Response of fly-ash on growth of Albizia procera in coal mine spoil and skeletal soil. Environmental Ecology. 15: 585-591.

[31] Srivastava A., and Chhonkar P. K., (2000). Amelioration of coal mine spoils through fly ash application on limiting material. Journal of Scientific and Industrial Research, (59) 4.

[32] Sylvia D.M., 1994. Vesicular-Arbuscular Mycorrhizal Fungi. Methods of soil Analysis, Part 2: Microbiological and Biochemical properties. SSSA, Book series, 5: 351-378.

[33] Tiwari S., Kumari B., and Singh S.N., 2008. Evaluation of metal mobility/immobility in fly ash induced by bacterial strains isolated from the rhizospheric zone of Typha latifolia growing on fly ash dumps. Bioresour. Technol., 99: 1305-1310.

[34] Weinstein L.H., Osmeloski J.F., Rutzke M., Beers A.O., McCahan J.B., Bache C.A., and Lisk D.J., 1989. Elemental analysis of grasses and legumes growing on soil covering coal fly ash landfill sites. J. Food Safety, 9: 291-300. 


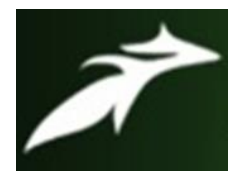

Debashis Kuila et al, International Journal of Advances in Agricultural Science and Technology, Vol.7 Issue.12, December-2020, pg. 71-80

ISSN: 2348-1358

Impact Factor: 6.057

NAAS Rating: 3.77

Table 1. Growth, Productivity and Mycorrhization status of Chilli at 90 d.a.p

\begin{tabular}{|c|c|c|c|c|c|c|c|c|c|c|c|c|c|}
\hline \multirow[b]{2}{*}{ Treatments } & \multirow[b]{2}{*}{ 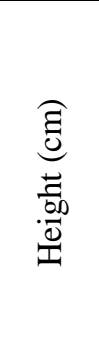 } & \multirow[b]{2}{*}{ 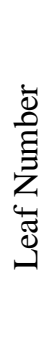 } & \multirow[b]{2}{*}{ 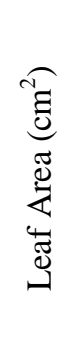 } & \multirow[b]{2}{*}{ 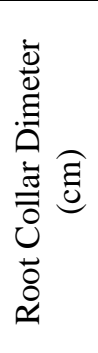 } & \multirow[b]{2}{*}{$\begin{array}{l}\bar{\Xi} \\
\bar{\Xi} \\
\Xi \\
Z \\
\overline{0} \\
\overline{0} \\
\overline{0}\end{array}$} & \multirow[b]{2}{*}{ 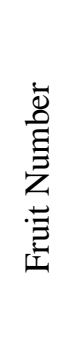 } & \multirow[b]{2}{*}{ 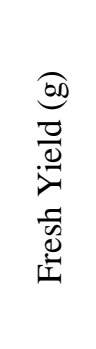 } & \multirow[b]{2}{*}{ 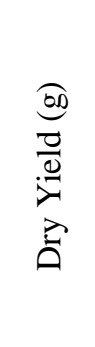 } & \multicolumn{4}{|c|}{ Mycorrhization } & \multirow[b]{2}{*}{ 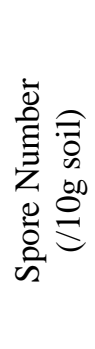 } \\
\hline & & & & & & & & & 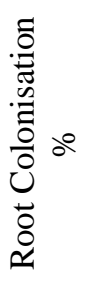 & $\begin{array}{l}0 \\
0 \\
0 \\
0 \\
0 \\
\frac{0}{2}\end{array}$ & $\begin{array}{l}\frac{0}{0} \\
\frac{0}{0} \\
\frac{0}{0} \\
0 \\
0\end{array}$ & 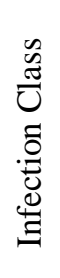 & \\
\hline LS & $17.9^{d}$ & 27 & 2.16 & 1.7 & 14 & $6^{d}$ & $11.3^{d}$ & $2.9^{c}$ & 16 & - & - & I & 28 \\
\hline FA & $19.7^{c}$ & 33 & 2.48 & 1.9 & 17 & $11^{\mathrm{c}}$ & $17.5^{\mathrm{d}}$ & $4.9^{b}$ & 38 & - & - & I & 137 \\
\hline $\mathrm{LS}+\mathrm{FA}$ & $21.4^{b}$ & 34 & 2.52 & 2.1 & 19 & $9^{c}$ & $16.9^{d}$ & $4.1^{b}$ & 25 & - & - & I & 91 \\
\hline $\mathrm{LS}+\mathrm{AM}$ & $20.6^{c}$ & 30 & 2.66 & 2.4 & 19 & $14^{b}$ & $25.4^{b}$ & $6.7^{b}$ & 35 & 14 & - & II & 55 \\
\hline $\mathrm{FA}+\mathrm{AM}$ & $25.3^{b}$ & 35 & 2.84 & 2.4 & 24 & $19^{\mathrm{a}}$ & $34.1^{b}$ & $9.1^{b}$ & 40 & - & - & II & 193 \\
\hline $\mathrm{LS}+\mathrm{FA}+\mathrm{AM}$ & $31.8^{\mathrm{a}}$ & 39 & 2.88 & 2.5 & 29 & $22^{\mathrm{a}}$ & $39.8^{\mathrm{a}}$ & $11.4^{\mathrm{a}}$ & 68 & 25 & 7 & III & 206 \\
\hline
\end{tabular}

Figure. Graphical representation of comparative parameters during the experiment
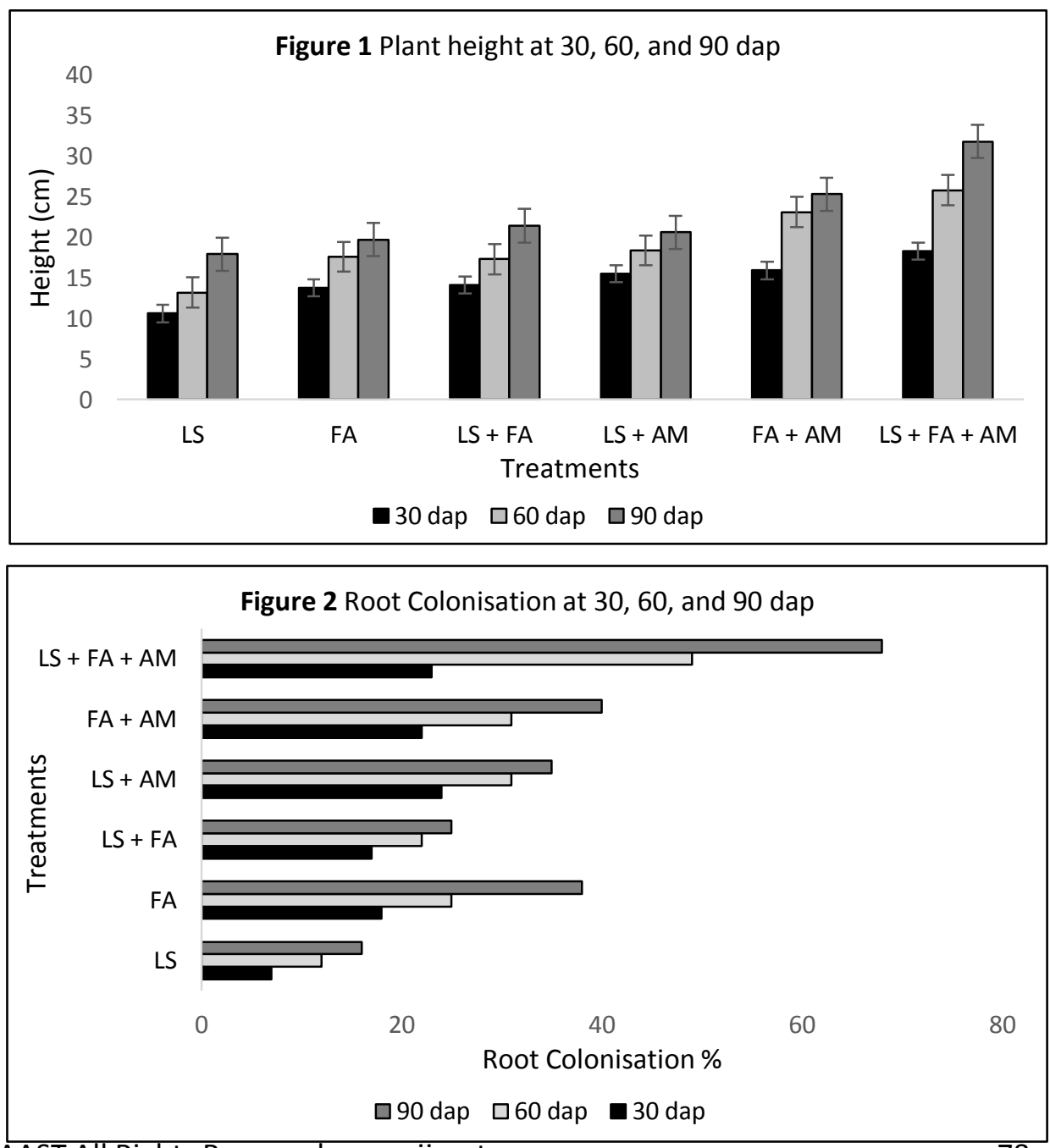


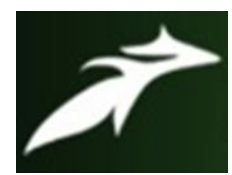

Debashis Kuila et al, International Journal of Advances in Agricultural Science and Technology, Vol.7 Issue.12, December-2020, pg. 71-80

ISSN: 2348-1358

Impact Factor: 6.057

NAAS Rating: 3.77

\section{Authors Biography}

Debashis Kuila -

- QUALIFICATION: B.Sc. (Microbiology Hons.), M.Sc. Microbiology.

Currently undergoing with Ph.D. in Botany.

- DESIGNATION : Ph.D. Fellow

- $\quad$ AFFLIATION: Department of Botany and Forestry, Vidyasagar University, Midnapore.

- Qualified GATE Life Sciences (2013).

- $\quad$ RESEARCH FELLOWSHIP: Junior Research Fellow (2013-2016), UGC.

- AREA OF RESEARCH: Application of mycorrhiza with beneficial microbes to enhance the growth of agricultural crops.

- MAILING ADDRESS: 207 B, Ramesh Dutta Sarani, Hijli Co-operative Society, Kharagpur-6.

- PHONE: 9476110445

- E-MAIL : dk89ian@gmail.com

- ORCID: orcid.org/0000-0001-9353-1289

\section{Bijoy Mal -}

- QUALIFICATION: B.Sc. (Botany Hons.), M.Sc. Botany and Forestry. Currently undergoing with Ph.D. in Botany.

- DESIGNATION : Ph.D. Fellow

- $\quad$ AFFLIATION: Department of Botany and Forestry, Vidyasagar University, Midnapore.

- $\quad$ Qualified GATE Life Sciences (2013).

- AREA OF RESEARCH: Applied Mycology, Ecology

- E-MAIL : bijaymalbotany@gmail.com

- ORCID: orcid.org/0000-0001-6282-1996

\section{Sudip Mondal -}

- QUALIFICATION: B.Sc. (Microbiology Hons.), M.Sc. Botany and Forestry. Currently undergoing with Ph.D. in Botany.

- DESIGNATION : Research Fellow

- $\quad$ AFFLIATION: Department of Botany and Forestry, Vidyasagar University, Midnapore.

- $\quad$ AREA OF RESEARCH: Applied Mycology, Biochemic Evaluation of different nutritional values.

- E-MAIL : sudipmondalprotein@gmail.com

- ORCID: orcid.org/0000-0003-1717-6355

\section{Somdatta Ghosh -}

- QUALIFICATION: M.Sc., Ph.D., B.Ed.

- DESIGNATION : Assistant Professor

- AfFliATION: Department of Botany (UG \& PG), Midnapore College (Autonomous), Midnapore.

- Awards and Recognitions:

- Silver medal and National scholarship for B.Sc. Hons.

- NET-UGC fellowship JRF\& SRF

- Member of Indian Mycological Society

○ Member of International Society for Tropical Ecology.

- AREA OF RESEARCH: Application of mycorrhiza and PGPR for soil sustainability.

- E-MAIL : somdattaghosh@yahoo.co.in

- ORCID: orcid.org/0000-0002-2558-8520 


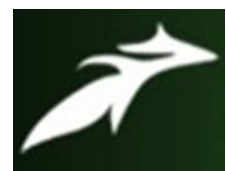

Debashis Kuila et al, International Journal of Advances in Agricultural Science and Technology, Vol.7 Issue.12, December-2020, pg. 71-80

ISSN: 2348-1358

Impact Factor: 6.057

NAAS Rating: 3.77

\section{Gunjan Biswas -}

- QUALIFICATION: M.Sc., Ph.D.

- DESIGNATION: Assistant Professor

- AFFLIATION: Department of Botany and Forestry, Vidyasagar University, Midnapore.

- Awards and Recognitions:

○ Professor S. N. Banerjee Gold Medal, Indian Mycological Society (2007).

- Member of International College of Nutrition (ICN) Life Membership No: 2009-15

- AREA OF RESEARCH: Applied Mycology; Profiling of fungi for different pharmacognostic parameters, Evaluation of different nutritional properties

- E-MAIL: gbiswas1211@gmail.com

- ORCID: orcid.org/0000-0001-8776-7762 